\title{
New Proposal to Define the Fascial System
}

\author{
Bruno Bordoni $^{a}$ Fabiola Marelli ${ }^{b, c}$ Bruno Morabito ${ }^{b, c}$ Roberto Castagna ${ }^{b}$ \\ Beatrice Sacconid,e Paul Mazzucco ${ }^{f}$
}

\author{
${ }^{a}$ Foundation Don Carlo Gnocchi IRCCS, Department of Cardiology, Institute of Hospitalization and Care with Scientific Address, \\ S. Maria Nascente, Milan, Italy; \\ ${ }^{b}$ CRESO, School of Osteopathic Centre for Research and Studies, Department of Fascial Osteopathic Research: FORe, \\ Gorla Minore, Italy; \\ ${ }^{c}$ CRESO, School of Osteopathic Centre for Research and Studies, Department of Fascial Osteopathic Research: \\ FORe, Fano, Italy: \\ dSapienza University of Rome, Department of Radiological, Oncological and Anatomopathological Sciences, Rome, Italy; \\ e Center for Life Nano Science@Sapienza, Istituto Italiano di Tecnologia, Rome, Italy; \\ ${ }^{f}$ AIOC, Italian Association of Classical Osteopathy, Rovigo, Italy
}

\section{Keywords}

Fascia $\cdot$ Myofascial · Skin · Connective tissue · Fibroblast

\section{Summary}

At the beginning of the third millennium, we still do not have a definition of 'fascia' recognized as valid by every researcher. This article attempts to give a new definition of the fascial system, including the epidermis, by comparing the mechanical-metabolic characteristics of the connective tissue and the skin. In fact, according to the latest classification deriving from the Fascia Nomenclature Committee, the outer skin layer is not considered as part of the fascial continuum. This article highlights the reasons for taking the functional characteristics of the tissue into consideration, rather than its mere structure. A brief discussion will address the questions as to what is considered as fascial tissue and from which embryonic germ layer the epidermis is formed. The notion that all the layers intersect will be highlighted, demonstrating that quoting precise definitions of tissue stratification in the living organism probably does not correspond to what happens in vivo. What we propose as a definition is not to be regarded as a point of arrival but as another departure.

(c) 2018 S. Karger GmbH, Freiburg

\section{Schlüsselwörter}

Faszie · Myofaszial · Haut · Bindegewebe $\cdot$ Fibroblasten

\section{Zusammenfassung}

Zu Beginn des dritten Jahrtausends verfügen wir noch immer nicht über eine Definition von «Faszie», die von allen Forschern als richtig anerkannt wird. In diesem Artikel wird versucht, eine neue Definition des faszialen Systems, einschließlich der Epidermis, zu entwerfen, indem die mechanisch-metabolischen Eigenschaften des Bindegewebes und der Haut verglichen werden. Tatsächlich wird laut der letzten Klassifikation durch das Fascia Nomenclature Committee die äußere Hautschicht nicht als Teil des faszialen Kontinuums angesehen. In diesem Artikel werden die Gründe dafür beleuchtet, warum die funktionellen Eigenschaften des Gewebes und nicht allein seine Struktur berücksichtigt werden sollten. In einer kurzen Diskussion wird darauf eingegangen, was als fasziales Gewebe anzusehen ist und von welchem embryonalen Keimblatt die Epidermis gebildet wird. Die Idee, dass alle Schichten miteinander verwoben sind, wird herausgestellt, sodass deutlich wird, dass das Zitieren von präzisen Definitionen der Bildung von Gewebeschichten im lebenden Organismus nicht dem entspricht, was in vivo passiert. Was wir als Definition vorschlagen, ist nicht als das Ende der Reise anzusehen, sondern als ein neuer Aufbruch.

\section{KARGER}

() 2018 S. Karger GmbH, Freiburg
Bruno Bordoni

Foundation Don Carlo Gnocchi IRCCS

Department of Cardiology, Institute of Hospitalization and Care with Scientific Address,

S. Maria Nascente

Via Capecelatro 66, Milan 20100, Italy

bordonibruno@hotmail.com 


\section{Introduction}

At the beginning of the third millennium, we still do not have a definition of 'fascia' recognized as valid by every researcher. There is no single definition of fascia, probably due to the scientific mark made by each professional figure in attempting to create a unique point of view [1-7].

Despite this situation of scientific uncertainty, it is thought and it can be found in textbooks - that the fascia covers every structure of the body, creating a structural continuity giving form and function to every tissue and organ $[8,9]$.

From the embryological perspective, the fascia originates in the mesoderm, although according to some authors this connective network can be partially found in the neural crest (ectoderm), with particular reference to the cranial and cervical area $[10,11]$.

We can identify 3 large groups of academics who are trying to give a definition of fascia. The Federative Committee on Anatomical Terminology (FCAT), founded in 1989 by the General Assembly of the International Federation of Associations of Anatomists (IFAA) [12], introduced the terms of 'fascia superficialis' and 'fascia profunda': The superficial fascia is understood as a 'whole loose layer of subcutaneous tissue lying superficial to the denser layer of fascia profunda' [13]. The deep fascia, according to this definition, lies under the superficial fascia, highlighting the presence of 2 fasciae. In 2011, the Federative International Program on Anatomical Terminologies (FIPAT), in agreement with the FCAT, gave this definition of fascia: 'A fascia is a sheath, a sheet, or any other dissectible aggregations of connective tissue that forms beneath the skin to attach, enclose, and separate muscles and other internal organs' [14]. The FIPAT founded the manual of international anatomical terminology: 'Anatomical Terminology'. In the second definition, we can more specifically find the term connective tissue, which has the function to divide, separate and support different structures. The FIPAT states that the connective tissue or fascia originates under the skin, excluding the epidermis from the fascial system.

The third group of academics who are involved in giving a definition of fascia is the Fascia Nomenclature Committee (2014), born from the Fascia Research Society founded in 2007 [14]. The committee gave the following description as a definition of fascia: 'The fascial system consists of the three-dimensional continuum of soft, collagen containing, loose and dense fibrous connective tissues that permeate the body. It incorporates elements such as adipose tissue, adventitiae and neurovascular sheaths, aponeuroses, deep and superficial fasciae, epineurium, joint capsules, ligaments, membranes, meninges, myofascial expansions, periostea, retinacula, septa, tendons, visceral fasciae, and all the intramuscular and intermuscular connective tissues including endo-/peri-/epimysium. The fascial system interpenetrates and surrounds all organs, muscles, bones and nerve fibers, endowing the body with a functional structure, and providing an environment that enables all body systems to operate in an integrated manner' [14]. The latter description is undoubtedly the broadest definition of fascia. The concept of the continuum of the structure that contains collagen/ connective tissue and the cellular diversity that makes up the fascia and the fact that the continuum itself guarantees the health of the body are emphasized.

Our Department of Fascial Osteopathic Research (FORe) wants to highlight some defective points and contradictions in these definitions, expanding the concept of fascia. This article attempts to give a new definition of the fascial system/fascia, including the epidermis, by comparing the mechanical-metabolic characteristics of the connective tissue and the skin. Different cells of different origin may have very similar functional characteristics.

\section{Collagen}

Collagen contains more than $30 \%$ of the protein mass of the human body. Its most common form is the collagen fibril, which is made up of tropocollagen units, i.e., polypeptide triple helices of about $300 \mathrm{~nm}$ in length. The fibril is highly organized and provides the protein framework for the extracellular matrix (ECM), the tendons, the bones, and for other supporting structures [15]. Collagen fibrils resemble self-assembling nanoscale wires. Minuscule subsidence points, like small imperfections or fragilities/weaknesses in the structure of the cables, can be found along each one of them. The weakness found in collagen fibrils is the imprint of the perfection of nature. In fact, these periodic imperfections enable the collagen fibril to handle the tension it perceives, adapting continuously: it reshapes itself to perpetuate its function [15]. The subsidence points are highly susceptible to tension variation sites, where metabolic processes important to regulate the remodeling/reshaping of the tissue of the fibrillar structure are initiated. These imperfections are like 'Trojan horses' where specialized proteolytic enzymes (matrix metalloproteinases (MMPs)) can more easily enter and start degradation and repair processes faster [15].

\section{Connective Tissue}

There are different types of connective tissue classified by morphological and functional criteria. We can find dense (fibrous or elastic) connective tissue, with irregular or regular collagen organizations, and loose (fibrous or elastic) connective tissue, characterized by the abundance of amorphous substance compared to the fibrous component. In dense connective tissue, collagen types I, III, $\mathrm{XII}$, and XIV and elastin are particularly present, while in the loose one we mainly find collagen types I, III, IV, V, VII, XII, and XIV [6].

Fibroblasts are the main cellular component of connective tissue and secrete components of the ECM such as collagen, glycosaminoglycans, elastic and reticulated fibers, and glycoproteins. They can differentiate into myofibroblasts when stimulated by transforming growth factor beta 1 TGF- $\beta 1$ ) and other pro-differentiation signals. Myofibroblasts develop alpha-smooth muscle actin ( $a$-SMA), which enables them to contract to facilitate wound healing, and upon completion of healing, they undergo apoptosis [16]. 
It is not easy to give a definition of the 'fibroblast'. For example, fibroblasts can produce collagen, transform into myofibroblasts and synthesize substances for the ECM. Pericytes are the connective tissue of vessels and are located in the microvascular base membrane, stimulating development and reshaping [17]. Fibroblasts, myofibroblasts, and pericytes produce proteins for the ECM and are located inside it; they have been shown to express a-SMA and vimentin, a stabilizing protein $[17,18]$.

The same fibroblasts in the same tissue may take different shapes and be designated by different names. For example, in tendons and ligaments, fibroblasts have an elongated shape and are referred to as tenocytes and ligamentocytes, respectively [19].

Fibroblasts may express different functions, depending on their position within the tissue. For example, fibroblasts located in the superficial (papillary) layer of the dermis fulfill different tasks and perform different actions than the ones located in the deep or reticular layers. The latter produce more collagen, proliferate more slowly and, in case of injury to the dermis, induce an altered behavior of keratinocytic cells [20].

Connective fibroblasts communicate with each other and are fundamental to the management of perceived and produced tension [9].

In the connective tissue, there are other types of cells that have not yet been entirely analyzed and catalogued.

In the superficial and deep fascial tissue that covers and divides the muscles, there are cells similar to fibroblasts and which are called fasciacytes. These cells are specialized in the production of hyaluronic acid (a high-molecular-weight glycosaminoglycan polymer of the ECM); the latter allows the dampening of tensions and the filling of cell spaces, and it also enables sliding of the different tissue layers [21]. Fasciacytes are probably located in fascial areas with a greater degree of innervation (more nerve endings, Pacini and Ruffini corpuscles) [22, 23].

Another cell type found in the connective tissue is the telocyte. There are not many studies on these cells in the fascial field, particularly in the thoracolumbar, crural, and plantar fascia, and in the fascia lata [24]. They can be found in many tissues of the human body and are involved in many biological processes [25].

Telocytes form a network inside the fascial network. They can form homocellular (among telocytes) and heterocellular junctions (between telocytes and fibroblasts, endothelial cells, stem cells, adipocytes, etc.) [25]. Through these contacts, they are able to influence the metabolic environment and play a part in repair and remodeling/reshaping processes. The exact role of these cells in the fascia is still unknown [24-26].

\section{Origin of the Collagens/Connective Tissue}

The connective tissue, which harbors many tissues that derive from it, has its origin in the mesenchyme $[13,14]$. During embryonic development, the connective tissue probably influences the shape (morphogenesis) of the structures it will later contain and connect [27].
The embryonic mesenchyme, or embryonic connective tissue or undifferentiated mesenchyme, is made up of star-shaped branched cells with a high mitotic rate (high reproductive capacity); they are considered as pluripotent cells because they can differentiate into several different tissues [28-30].

The mesenchyme can be found in and derives from all 3 embryonic layers (ectoderm, mesoderm, endoderm), especially from the mesoderm and the ectoderm [31, 32].

According to the information we are currently aware of, all the structures within the definition of fascia that are part of the head (muscles, bones, skin, etc.) and part of the cervical tract derive from the mesoderm and the ectoderm $[33,34]$.

\section{Skin}

The 2 most important layers of the skin are the epidermis and the underlying dermis. The epidermis is the surface epithelium that originates in the ectoderm, meaning that it is part of the structures that are in contact with the outside world [35]. Some authors also identify a third layer, the hypoderm, which lies under the dermis and is rich in adipocytes [36].

The epidermis is rich in cells called keratinocytes (95\% of the total cells) and which synthesize a protein called keratin. The most superficial skin layer is again made up of different layers: the basal or germinative (the deepest) layer, the spinous layer, the granular layer, and the stratum corneum (corneal layer; the most superficial layer) [37]. We can identify a fifth layer where the skin is thicker, such as the palms of the hands and the soles of the feet. The polished layer is located between the granular layer and the corneal layer [38].

The remaining approximately $5 \%$ consists of cells such as melanocytes (they produce melanin), Merkel cells (for the sense of touch), and Langerhans cells (as the first immune barrier) [36-38].

Keratinocytes migrate in the human body from the basal layer to the stratum corneum, where they die, in cycles of 40 days.

The keratinocytes allow preservation of the homeostasis of the epidermis and of the framework of the skin; they defend the skin against potentially harmful external/internal agents by secreting cytokines and chemokines, affecting the immune system [39].

Mechanical tension is a determining factor in the behavior of keratinocytes, just like in the case of fibroblasts [40]. Keratinocytes are sensitive to various types of internal and/or external mechanostimuli, which significantly affect the skin morphology. Mechanosensors such as p130Cas are located on the keratinocytes; p130Cas is a protein that, when triggered by deformation of the skin, stimulates the keratinocytes to proliferate [41]. Like all living cells exposed to numerous mechanical stimuli, the epidermis senses tension variations while maintaining its mechanical-metabolic homeostasis and structure. The stretching-contracting movement of the skin stimulates the opening of calcium channels, whose ions activate some proteins (e.g., phospholipase $\mathrm{C}$ and protein kinase $\mathrm{C}$ ) that migrate from the cytoplasm to the membrane of the 
keratinocyte, thus allowing it to adapt to mechanical stress [42]. The framework of the cell (cytoskeleton), which mainly consists of keratin, acts as a mechanosensor and transducer of the present mechanical tension. Keratin is able to extend beyond the boundaries of the keratinocyte, contacting nearby cells to mechanically integrate the tissue as a whole $[42,43]$. The keratinocytes are elastic and able to produce minimal movements. These characteristics probably allow the entire epidermis to act as a unit in the presence of mechanical alterations.

Another protein contained in the epidermis is plectin, also found in muscle cells. This protein probably stabilizes cytokeratin in the presence of mechanical stresses, allowing it to produce adequate mechanotransductive responses [44].

The dermis is the layer underneath the epidermis; it derives from the ectoderm (neural crest) for the head and the neck, from the lateral plate of the mesoderm for the limbs and the anterior area of the trunk, and from the paraxial mesoderm for the back. The dermis nourishes and supports the epidermis and binds it to the hypoderm (fat). We can identify a more superficial or papillary layer and a deeper or reticulated layer [36]. In the dermis, there are important cellular structures such as fibroblasts, mastocytes, and macrophages; keratinocytes and fibroblasts communicate between the basal epidermis layer and the papillary layer of the dermis [37]. This relation between keratinocytes and fibroblasts is very close and makes the skin stronger in the presence of mechanical stress [45].

The fibroblasts in the dermis have the ability to stimulate the proliferation of keratinocytes and to interact with the epidermis for repair processes, and vice versa $[45,46]$. Keratinocytes stimulate fibroblasts to synthesize growth factors and cytokines (keratinocyte growth factor (KGF), fibroblast growth factor-7 (FGF-7), interleukin (IL)-1, IL-6, and granulocyte-macrophage colony-stimulating factor (GM-CSF)), which in turn will stimulate major epidermal cells to proliferate, in a double paracrine manner. At the same time, with such a metabolic environment, fibroblasts will acquire the phenotypic characteristics of myofibroblasts under the control of keratinocytes [47]. KGF is able to stimulate fibroblasts to produce TGF- $\beta 1 /$ CTGF (connective tissue growth factor), which will induce the transformation into myofibroblasts for tissue repair [47, 48].

A protein found in both the connective tissue and the dermis is the telocyte $[24,49]$. Adipose tissue is either white or dermal white adipose tissue (DWAT) [50].

\section{Discussion}

We know that the dermis is considered as part of the definition of fascia and that the mesoderm is the cradle of the fascial tissue; yet, the dermic areas of the head and the neck derive from the ectoderm, as does the whole epidermis. This information highlights the shortcomings and the contradictions of the current classifications of fascia.

The layers are inseparable, and they move and respond in unison to the presence of mechanometabolic information $[51,52]$.
The keratinocytes and the fibroblasts of the dermis mutually and simultaneously influence each other. In the connective tissue organization from the skin to the bone, the collagen fibrils form a network in the absence of genuinely separate layers, as the same structures are found from the surface to the depth; the so-called layers are only distinguishable due to the different fibrillar density [53].

We know that fibroblasts and keratinocytes respond in the presence of mechanical stimuli by secreting growth factors and cytokines, thus affecting the surrounding cell environment, and by changing their morphology based on the nature of the mechanometabolic information they receive. In response to the application of forces, the strain-induced mechanical stimulation of the cells and their associated ECM gives them the ability to directly regulate integrin expression, focal adhesion proteins, the cytoskeletal organization, cell morphology, cell adhesion to the ECM, cell proliferation, and cell differentiation, thus influencing the shaping of the fascia. Likewise, the cell has the ability to transfer the tension generated by its cytoskeleton to ECM proteins, influencing their behavior and shape [54].

From what we have just said, we believe that excluding the epidermis from the fascial system definition does not make full sense of the fascial tissue itself. It is a solution that does not reflect the reality in the actual scientific situation.

The everyday movements of the body are possible thanks to the presence of the fascial tissues and their inseparable interconnections, which allows the sliding of the muscular framework, the sliding of nerves and vessels between/around contractile fields and joints, in the same way as all the organs can slide and move among each other, influenced by the position of the body [24]. An alteration of the bodily movements would have a negative influence on the neural, peripheral, and central processes, which would induce modifications in the motor patterns $[55,56]$. The epidermis itself, in the presence of an illness, can negatively affect these bodily movements, locally and systematically, as well as the entire connective system (scleroderma) [57]. Also, through somatic-visceral reflexes starting from the epidermis, the skin is able to influence the emotional and visceral behavior, and it consequently causes changes in the bodily posture [58-60].

The fascial unit influences not only the movements but also the emotions. The presence of a disorder of the myofascial continuum during the everyday movements and activities can alter the emotional state of a person. The human being is a fascia that walks. We are the living expression of bio-tensegrity. In other words, the presence of discontinuous compression elements (bones) balances the stress generated or received by continuous tension elements (muscle and fascia) $[53,61]$.

The visceral fascial system may interact with the skin through the viscera-somatic pathways, affecting its metabolic behavior [62, 63].

The epidermis influences the response of myofascial nociceptors in the presence of neuropathic pain. It has been shown that, in certain pathological situations, the activation of tactile epidermis afferents through mechanical stimuli activates a nociceptive re- 
sponse of the myofascial mechanocytes during a movement, triggering the phenomenon of allodynia [64]. In this situation, the common medullary pathways of the lamina I (the dorsal horns) are probably stimulated, projecting afferents to the ventral-posterior thalamic nucleus, which will project information towards the posterior-dorsal insular cortex (limbic area) [64].

Our definition hypothesis is thus: 'The fascia is any tissue that contains features capable of responding to mechanical stimuli. The fascial continuum is the result of the evolution of the perfect synergy among different tissues, capable of supporting, dividing, penetrating and connecting all the districts of the body, from the epidermis to the bone, involving all the functions and organic structures. The continuum constantly transmits and receives mechanometabolic information that can influence the shape and function of the entire body. These afferent/efferent impulses come from the fascia and the tissues that are not considered as part of the fascia in a biunivocal mode.'

Our definition is not to be considered as a point of arrival but as another departure.

\section{Conclusions}

There is currently no unanimous definition of fascial tissue. There are different views and scientific competencies from which the descriptions of the fascia are born. This article has discussed the functional characteristics of the connective tissue and the epidermis, emphasizing the mechanometabolic complicity between fibroblasts and keratinocytes. A brief analysis was made of the fact that the epidermis should fall within the definition of the fascial continuum, and of how much the skin can affect the bodily system.

We are still far from being able to give a definition that is accepted by every researcher. Considering that there are cellular and metabolic aspects that have not been exhaustively analyzed yet, it will take some time to fully understand the functions of the fascial system, and more studies and research will be required to obtain a proper and descriptive classification that focuses on what the fascia really is.

\section{Disclosure Statement}

The authors report no conflicts of interest in this work.

\section{References}

1 Schleip R, Klingler W: Schleip \& Klingler's response to Stecco's fascial nomenclature editorial. J Bodyw Mov Ther 2014;18:447-449.

2 Tozzi P: Tozzi's response to Stecco's fascial nomenclature editorial. J Bodyw Mov Ther 2014;18:450-451.

3 Myers T: Myers' response to Stecco's fascial nomenclature editorial. J Bodyw Mov Ther 2014;18:445-446.

4 Langevin H: Langevin's response to Stecco's fascial nomenclature editorial. J Bodyw Mov Ther 2014;18:444.

5 Natale G, Condino S, Soldani P, Fornai F, Mattioli Belmonte M, Gesi M: Natale et al.'s response to Stecco's fascial nomenclature editorial. J Bodyw Mov Ther 2014;18:588-590

6 Kumka M: Kumka's response to Stecco's fascial nomenclature editorial. J Bodyw Mov Ther 2014;18:591-598.

7 Stecco C: Why are there so many discussions about the nomenclature of fasciae? J Bodyw Mov Ther 2014;18: 441-442.

8 Bordoni B, Marelli F: The fascial system and exercise intolerance in patients with chronic heart failure: hypothesis of osteopathic treatment. J Multidiscip Healthc 2015;8:489-494.

$\checkmark 9$ Bordoni B, Zanier E: Understanding fibroblasts in order to comprehend the osteopathic treatment of the fascia. Evid Based Complement Alternat Med 2015; 2015:860934.

10 Bordoni B, Zanier E: Clinical and symptomatological reflections: the fascial system. J Multidiscip Healthc 2014;7:401-411.

11 Bordoni B, Marelli F: Emotions in motion: myofascial interoception. Complement Med Res 2017;24:110-113.

12 Wendell-Smith CP: Fascia: an illustrative problem in international terminology. Surg Radiol Anat 1997;19: 273-277.

13 Schleip R, Jäger H, Klingler W: What is 'fascia'? A review of different nomenclatures. J Bodyw Mov Ther 2012;16:496-502.

14 Adstrum S, Hedley G, Schleip R, Stecco C, Yucesoy CA: Defining the fascial system. J Bodyw Mov Ther 2017; 21:173-177.
15 Dittmore A, Silver J, Sarkar SK, Marmer B, Goldberg GI, Neuman KC: Internal strain drives spontaneous periodic buckling in collagen and regulates remodeling. Proc Natl Acad Sci USA 2016;113:8436-8441.

16 Nithiananthan S, Crawford A, Knock JC, Lambert DW, Whawell SA: Physiological fluid flow moderates fibroblast responses to TGF- $\beta 1$. J Cell Biochem 2017;118: 878-890.

17 Chapman MA, Meza R, Lieber RL: Skeletal muscle fibroblasts in health and disease. Differentiation 2016;92: 108-115

18 Murphy S, Ohlendieck K: The biochemical and mass spectrometric profiling of the dystrophin complexome from skeletal muscle. Comput Struct Biotechnol J 2015; 14:20-27.

19 Shukunami C, Yoshimoto Y, Takimoto A, Yamashita $\mathrm{H}$, Hiraki Y: Molecular characterization and function of tenomodulin, a marker of tendons and ligaments that integrate musculoskeletal components. Jpn Dent Sci Rev 2016;52:84-92.

20 Kwan PO, Tredget EE: Biological principles of scar and contracture. Hand Clin 2017;33:277-292.

21 Stecco C, Stern R, Porzionato A, Macchi V, Masiero S, Stecco A, De Caro R: Hyaluronan within fascia in the etiology of myofascial pain. Surg Radiol Anat 2011;33: 891-896.

22 Stecco C, Corradin M, Macchi V, Morra A, Porzionato A, Biz C, De Caro R: Plantar fascia anatomy and its relationship with Achilles tendon and paratenon. J Anat 2013;223:665-676.

23 Stecco C, Cappellari A, Macchi V, Porzionato A, Morra A, Berizzi A, De Caro R: The paratendineous tissues: an anatomical study of their role in the pathogenesis of tendinopathy. Surg Radiol Anat 2014;36:561-572.

24 Dawidowicz J, Matysiak N, Szotek S, Maksymowicz K: Telocytes of fascial structures. Adv Exp Med Biol 2016; 913:403-424.

25 Dawidowicz J, Szotek S, Matysiak N, Mielańczyk Ł, Maksymowicz K: Electron microscopy of human fascia lata: focus on telocytes. J Cell Mol Med 2015;19:25002506.
26 Szotek S, Dawidowicz J, Eyden B, Matysiak N, Czogalla A, Dudzik G, Leśniewicz A, Maksymowicz K: Morphological features of fascia lata in relation to fascia diseases. Ultrastruct Pathol 2016;40:297-310.

27 Blasi M, Blasi J, Domingo T, Pérez-Bellmunt A, Miguel-Pérez M: Anatomical and histological study of human deep fasciae development. Surg Radiol Anat 2015;37:571-578.

28 Breznik B, Motaln H, Vittori M, Rotter A, Turnšek TL: Mesenchymal stem cells differentially affect the invasion of distinct glioblastoma cell lines. Oncotarget 2017;8:25482-25499.

29 Shirjang S, Mansoori B, Solali S, Hagh MF, Shamsasenjan K: Toll-like receptors as a key regulator of mesenchymal stem cell function: an up-to-date review. Cell Immunol 2017;315:1-10.

30 Young B, Woodford P, O’Dowd G: Wheater's Functional Histology: A Text and Colour Atlas, ed 6. Amsterdam, Elsevier, 2013, p 65

31 Schmidt C, Stoeckelhuber M, McKinnell I, Putz R, Christ B, Patel K: Wnt 6 regulates the epithelisation process of the segmental plate mesoderm leading to somite formation. Dev Biol 2004;271:198-209.

32 Grapin-Botton A, Melton DA: Endoderm development: from patterning to organogenesis. Trends Genet 2000;16:124-130.

33 Goodnough LH, Dinuoscio GJ, Ferguson JW, Williams $\mathrm{T}$, Lang RA, Atit RP: Distinct requirements for cranial ectoderm and mesenchyme-derived Wnts in specification and differentiation of osteoblast and dermal progenitors. PLoS Genet 2014;10:e1004152.

34 Mariani FV, Fernandez-Teran M, Ros MA: Ectodermmesoderm crosstalk in the embryonic limb: the role of fibroblast growth factor signaling. Dev Dyn 2017;246: 208-216.

35 Bordoni B, Zanier E: Skin, fascias, and scars: symptoms and systemic connections. J Multidiscip Healthc 2013; 7:11-24.

36 Arda O, Göksügür N, Tüzün Y: Basic histological structure and functions of facial skin. Clin Dermatol 2014; 32:3-13. 
37 Barcaui Ede O, Carvalho AC, Piñeiro-Maceira J, Barcaui $\mathrm{CB}$, Moraes H: Study of the skin anatomy with high-frequency $(22 \mathrm{MHz})$ ultrasonography and histological correlation. Radiol Bras 2015;48:324-329.

38 Patel R, Kevin Heard L, Chen X, Bollag WB: Aquaporins in the skin. Adv Exp Med Biol 2017;969:173-191.

39 McKelvey K, Jackson CJ, Xue M: Activated protein C: a regulator of human skin epidermal keratinocyte function. World J Biol Chem 2014;5:169-179.

40 Lieber AD, Yehudai-Resheff S, Barnhart EL, Theriot JA, Keren K: Membrane tension in rapidly moving cells is determined by cytoskeletal forces. Curr Biol 2013;23: 1409-1417.

41 Takeya M, Okumura Y, Nikawa T: Modulation of cutaneous extracellular collagen contraction by phosphorylation status of p130Cas. J Physiol Sci 2017;67:613622.

42 Reichelt J: Mechanotransduction of keratinocytes in culture and in the epidermis. Eur J Cell Biol 2007;86 807-816.

43 Cherbuin T, Movahednia MM, Toh WS, Cao T: Investigation of human embryonic stem cell-derived keratinocytes as an in vitro research model for mechanical stress dynamic response. Stem Cell Rev 2015;11: 460-473.

44 Bonakdar N, Schilling A, Spörrer M, Lennert P, Mainka A, Winter L, Walko G, Wiche G, Fabry B, Goldmann WH: Determining the mechanical properties of plectin in mouse myoblasts and keratinocytes. Exp Cell Res 2015;331:331-337.

45 Lawlor KT, Kaur P: Dermal contributions to human interfollicular epidermal architecture and self-renewal. Int J Mol Sci 2015;16:28098-28107.
Driskell RR, Watt FM: Understanding fibroblast heterogeneity in the skin. Trends Cell Biol 2015;25:92-99.

47 Werner S, Krieg T, Smola H: Keratinocyte-fibroblast interactions in wound healing. J Invest Dermatol 2007; 127:998-1008.

48 Zhang C, Lim J, Liu J, Ponugoti B, Alsadun S, Tian C, Vafa R, Graves DT: FOXO1 expression in keratinocytes promotes connective tissue healing. Sci Rep 2017;7: 42834.

49 Rusu MC, Mirancea N, Mănoiu VS, Vâlcu M, Nicolescu MI, Păduraru D: Skin telocytes. Ann Anat 2012;194:359-367.

50 Driskell RR, Jahoda CA, Chuong CM, Watt FM, Horsley V: Defining dermal adipose tissue. Exp Dermatol 2014;23:629-631.

51 Scarr G: Comment on 'Defining the fascial system'. J Bodyw Mov Ther 2017;21:178.

52 Stecco C, Schleip R: A fascia and the fascial system. J Bodyw Mov Ther 2016;20:139-140

53 Bordoni B, Marelli F, Morabito B, Sacconi B: The indeterminable resilience of the fascial system. J Integr Med 2017;15:337-343.

54 Cukierman E, Pankov R, Yamada KM: Cell interactions with three-dimensional matrices. Curr Opin Cell Biol 2002;14:633-639.

55 Schleip R, Mechsner F, Zorn A, Klingler W: The bodywide fascial network as a sensory organ for haptic perception. J Mot Behav 2014;46:191-193.

56 Stecco A, Stern R, Fantoni I, De Caro R, Stecco C: Fascial disorders: implications for treatment. PM R 2016;8: 161-168.
7 Nikitorowicz-Buniak J, Denton CP, Abraham D, Stratton R: Partially evoked epithelial-mesenchymal transition (EMT) is associated with increased TGF $\beta$ signaling within lesional scleroderma skin. PLoS One 2015; 10:e0134092.

58 Camilleri M, Malagelada JR, Kao PC, Zinsmeister AR Effect of somatovisceral reflexes and selective dermatomal stimulation on postcibal antral pressure activity. Am J Physiol 1984;247(6 Pt 1):G703-G708.

59 Stemmler G, Aue T, Wacker J: Anger and fear: separable effects of emotion and motivational direction on somatovisceral responses. Int J Psychophysiol 2007;66: 141-153.

60 Hao N, Xue H, Yuan H, Wang Q, Runco MA: Enhancing creativity: proper body posture meets proper emotion. Acta Psychol (Amst) 2017;173:32-40.

61 Turvey MT, Fonseca ST: The medium of haptic perception: a tensegrity hypothesis. J Mot Behav 2014;46: 143-187.

62 Licciardone JC, Fulda KG, Stoll ST, Gamber RG, Cage AC: A case-control study of osteopathic palpatory findings in type 2 diabetes mellitus. Osteopath Med Prim Care 2007; 1:6.

63 Jørgensen LS, Fossgreen J: Back pain and spinal pathology in patients with functional upper abdominal pain. Scand J Gastroenterol 1990;25:1235-1241.

64 Jänig W: Mechanical allodynia generated by stimulation of unmyelinated afferent nerve fibres. J Physiol 2011;589(Pt 18):4407-4408. 